\title{
Economic Impact of Climate Change on the Agricultural Sector of Punjab
}

\author{
UZMa HANIF, SHABIB HAIDER Syed, RAFIQUe AHMAD, and \\ KAUSER ABDULlah MALIK
}

The aggregate global effects on agricultural productivity are expected to be negative by the late of this century, and developing countries are expected to suffer sooner and worse. ${ }^{1}$

\section{PREAMBLE}

As back as the Industrial Revolution, anthropogenic activities namely, power generation from fossil fuels and deforestation activities have been continuously increasing the atmospheric concentration of GHGs beyond their natural limits resulting in an enhanced greenhouse effect, vis-à-vis, an increase in global temperature. The rise in temperature could be coupled with changes in rainfall pattern, rise in sea level, and frequency and severity of extreme events namely, cyclones and droughts etc. The sum of all these changes is referred to as climate change. Climate change affects economic development in many ways, especially the agrarian economies have always depended on vagaries of nature and climate. Change in temperature, precipitation averages and extreme climate events can alter yield, income, health, sociology and physical safety. Climate change is a global phenomenon and no country is immune to it.

The disappearing of the Himalayan glaciers at a fast pace would increase the probability of extreme water flows, rendering it uncontrolled will bring heavy floods, loss of life, livestock, crops and infrastructural facilities in Pakistan, India, Nepal and Bangladesh. Climate change will affect all sectors of the economy not alone agricultural sector the most as well as health, forests, energy, coastal area, biodiversity and ecology all over the globe. In this connection, it will be pertinent to give the most recent events which have taken place across Asia.

Uzma Hanif<uzmahanif@fccollege.edu.pk> is Assistant Professor, Department of Economics, Forman Christian College (A Chartered University), Lahore. Shabib Haider Syed is Associate Professor and Chairman, Department of Economics, Forman Christian College (A Chartered University), Lahore. Rafique Ahmad is formerly Vice-Chancellor of Universities of Punjab and Bahawalpur, Professor Emeritus, Centre for South Asian Studies, University of the Punjab. Kauser Abdullah Malik is Professor, Department of Biological Sciences, Forman Christian College (A Chartered University), Lahore. Member, Task Force on Climate Change, Chairing Agriculture Section, Government of Pakistan.

${ }^{1}$ Climate Change, Human Vulnerability and Social Risk Management. Social Developmet Group, The World Bank Group (Rasmus Heltberg. Steen Lau Jorgensen and Paul Bennet Siegel (2008). 
The deadly mudsliding in Zhugqu county in China in August, 2010 was caused by heavy rains and floods. Some 1,248 people have perished in the mudslides and an equal number were rescued. The number of missing persons was reported to be $496{ }^{2}$

The history's worst ever flood of Pakistan in July and August 2010 were the result of heavy monsoon rains. According to an estimate of United Nations over 20 million people have been affected, and 1,60,000 square kilometer lands flooded. This has exceeded the number of combined total affectees of 2004 Indian Ocean Tsunami, the 2005 Kashmir earthquake and the 2010 Haiti earthquake. ${ }^{3}$ At a time when Pakistan is encountered to extreme monsoon, China is mourning over the loss of human life caused by mudsliding, Russia is having a record breaking heat wave that has seen Moscow with smog from burning peatlands. Russian economists have said that they estimate the heatwave and wildfires to cut $\$ 15 \mathrm{bn}$ ( $£ 9 \mathrm{bn}$ ) from economic output. ${ }^{4}$

Agricultural has been one of the oldest economic activities in all over the world. It is not only the backbone of foodgrain supply to the work force but also supply raw material to industries. Depending upon the natural resources, agricultural sector is vulnerable to climatic change and vagaries of nature.

Climate change has raised serious concerns for developing countries and Pakistan is not alone to face tremendous social, environmental and economic impacts. The many impacts on agricultural due to climate change have received a high contemplations in Pakistan. As the change in climate is closely linked to food security and poverty of a vast majority of the country's population. Pakistan's status as a developing country is dependent mainly on agricultural sector making it highly vulnerable to the effects of climate change. Agricultural and allied activities are the single largest sector, contributing 21 percent to GDP and employing 44 percent of workforce. As much as 65 percent foreign exchange is earned from export of goods manufactured from raw material obtained from agricultural sector. More than two-third of Pakistan population lives in rural areas and their livelihood depend on agricultural and agro-based activities (Pakistan Economic Survey, 2007-08).

In 2006, the share of agricultural sector in GDP, exports and employment level have markedly decreased. Amongst other reasons of declining agricultural productivity, change in climate has been marked a major contributor. According to Economic Survey (2007-08), agricultural sector has performed poorly in 2007-08, it grew at 1.5 percent against the target of 4 percent. The sector had suffered from multifarious reasons which also included heavy rainfall in May 2007, high temperature during August and September, 2007 and shortage of water in the overall irrigation system.

Concerns about potential adverse impacts of climate change have triggered which could be named as impact assessment research since the early 1990s. Over the past two decades, the impact assessment research has gone through a metamorphosis with gradual movement towards vulnerability and adaptation assessment. Impact assessment studies have continued on a wider horizon in order to evolve both innovations in methodology and scope of analysis.

\footnotetext{
${ }^{2}$ http://news.xinhuanet.com/english2010/china/2010-08/14/c_13444285.htm

${ }^{3}$ http://www.bbc.co.uk/news/world-south-asia-10984477

${ }^{4}$ http://www.bbc.co.uk/news/world-europe-10932644
} 
It is documented in final report of Task Force, Planning Commission $\mathrm{GoP}^{5}$ on Climate Change that there is a dire need to quantify the impact of climate change on different sectors of the economy for planning and policy making. The report has also noted that it is not easy to assess the economic impact of climate change on different sectors of the economy. But it is of very crucial importance for national planners and policymakers to develop and shape the country's development plans in the most optimal manner within the constraints of limited available resources. Viewed in this perspective, the study in hand is the first effort to quantify the impact of climate change on agricultural sector. Rabi and Kharif are two sowing and harvesting seasons in Pakistan. It has considered Rabi and Kharif mean precipitation, minimum and maximum temperature individually as climate variables. By using Feasible Generalised Least Square technique of panel regression estimations, relationships of climate variables with agricultural land price as well as marginal climate impacts are calculated. Results also reveal the magnitude of change in per acre agricultural land price with change of climate variables. The study has confirmed the hypothesis that climate change impinches considerably price of agricultural land which is a long run variable for net revenues.

The study area in hand is the Punjab province of Pakistan. Punjab is the most populous and the second largest province of Pakistan. Agricultural sector dominates the Punjab landscape both in the percentage of land (57.2 percent) in agricultural sector and also the percentage share (53 percent) of Pakistan's agricultural gross domestic product (Punjab Development Statistics, 2009). In the year 2007-08 the Punjab share in Pakistan's agricultural production of major crops was wheat 74.5 percent. Rice 59.1 percent, gram 81.7 percent, Jawar 612 percent, maize 74.5 percent, Bajra 73.4 percent, cotton 77.8 percent, sugarcane 63.1 percent, barley 33.3percent, rapeseed and mustard 58.5percent. For major fruits, Punjab's share in the overall country's production was mango 78.3 percent, banana 6.3 percent, citrus 96.7 percent, guava 78.3 percent, dates 7.9 percent and apple 0.7 percent (Punjab Development Statistics, 2009).The capacity of Punjab agricultural sector adaptability to the changing climate has never been investigated. Developing a comprehensive understanding of this adaptation capacity will facilitate efficient and viable agricultural policy reforms in the context of climate change. Study in hand is pioneering in quantifying the economic impact of climate change. By considering the results and policy recommendation, policy makers can develop climate policies based upon ground realities.

\section{REVIEW OF LITERATURE}

\subsection{Historical Background}

A Swedish Nobel prize laureate, chemist cum physicist, Arrhenius (1896) was the first scientist who speculated that concentration of carbon dioxide in the atmosphere could substantially alter the global temperature from greenhouse effect.

The debate of greenhouse effect entered in the domain of economics by Nordhaus (1982), who has discussed in his article that how change in climate from concentration of carbon dioxide impacts the economy. Nordhaus (1982) noted that climate change

${ }^{5}$ Final Report, Task Force on Climate Change, Planning Commission of Pakistan, 2010. 
impact is channelised into the economy in two ways; first production side and second is the economy through the policy induced abatement activities.

The potential adverse impacts of climate change on the economy have triggered which have started impact assessment research since early 1990s [Kumar (2009)]. Impact assessment has lead to positive and normative policy for adaptation and mitigation of effects due to climate change.

\subsection{Hedonic Price Method}

Hedonic method is derived from Ricardian approach. The Ricardian Approach has been based on the observation by David Ricardo (1772-1823). It has stated that farmers maximise their profits by using land in the declining order of fertility i.e. climate and soil quality etc. The land with the most suitable climate for the most profitable agricultural activity will be put to that use [Polsky (2004)]. The approach measures the climate and other factors affecting the net farm output, net revenue or land values [Mendelsohn, Nordhaus, and Shaw (1994)]. As can be seen, this cross-sectional methodology used for agricultural production is a direct measurement of climate sensitivity. Its application is across locations besides the adaptation response by farmers to local climate profile.

Schlenker, et al. (2006) has opined that the Ricardian approach is a hedonic method of farmland pricing that assumes the value of a tract of land equals the discounted value of the stream of future rents or profits that can be derived from it.

\subsection{Land Climate Hedonic Price Method}

Rosen (1974) has suggested that hedonic relation will arise due to the heterogeneity in quality of the attributes of the goods. Agricultural land prices are dependent upon factors that determine agricultural productivity i.e. climate (max, min temperatures, precipitations, solar radiation etc.), soil quality and slope (flat vs. hilly). [Kolstad (2000)]. Goulder and Pizer (2006) have opined that "applied to agricultural, the hedonic approach has aimed to embrace a wider range of substitution options, employing cross-section data to examine how geographical, physical and climate variables have been related prices of agricultural land.

From the discussion of Ricardian approach and Hedonic Method, it may or should not be construed that the two models overlap each other. As Ricardian approach is based upon Hedonic Method, they supplement and complement.

\subsection{Land Climate Hedonic Price Studies}

Mandelshon, et al. (1994) have introduced hedonic agricultural land climate price to link land value to land characteristics including climate factors. By regressing the per acre annual value for cropland, pasture and grazing for counties across the United States on climate and other control variables, they found that there is a quadratic relationship between farm land and climate variables.

In a subsequent paper Mandelshon, et al. (1996) have further expanded the method by using aggregate farm value per acre in a county. The result indicated that climate change not only affects the value of existing farms but also the probability that land would be farmed in the years coming ahead. 
Maddison (2000) employed the Hedonic Land Climate Price Method to estimate the marginal value of various farmland characteristics in England and Wales. His findings have revealed that climate, soil quality, and elevation, in addition to the structural attributes of farmland, were significant determinants of farmland prices.

Reinsborough (2003) had opined that climate change effects will be negligible for the Canadian agricultural sector. Some economists have prediction that the potential benefits of climate change lie in shifting from temperature to tropical crops with climate change. According to Reinsborough (2002), "this might be able to moderate negative effects in Canada. However, it did not appear to induce dramatic increase in farmland value or farm revenues.

The study had incorporated the socio-economic variables (1996 Census of Canada), and farm variables [Agricultural Census (1996)]. Soil classification, climatic data were obtained from National Ecological framework.

Global Information System (GIS) software "Arc Info" was used for ecological data (district level), and weightage was done of each eco district fell which within the each agricultural Census Division and ecological values calculated for the 267 Census Divisions. In case of missing data for one or more variables for ecological district (16 of 1,022), the data from neighbouring ecological districts were assigned.

Time series data from 1961-90 was used for econometric analysis. Monthly climatic normals (temperature and precipitation) were used as climate changes had longer term trends rather than short-term variations. The relationship between climate and agricultural was estimated with farm value as dependent variable. The linear terms represented the marginal value of climate. The Canadian means was represented by the linear terms and the quadratic mean reflected the marginal effects as one moved away from the mean. Whit's heteroscedasticity consistent estimators were used being the robust standards error.

Socio-economic variables were chosen to reflect the potential of land in alternate uses. Income per capita as indicator of being wealthy and population density (and its square term) captured the urban/rural characteristics. Migration reflected the growing areas or areas in decline which would affect land value and also its future use.

The environmental variable namely latitude showed the nearness of an area as well as it provided a proxy for the length of day. Solar radiation was also included as an important determinant of farm returns. The clay and sand contents were included as rough proxies for soil quality. Irrigation was included in the original analysis but omitted, as it was deemed an endangered variable with insignificant effect on the resultant value. The result showed that there were minor positive benefits from climate change within wide uncertainty for the Canadian agricultural sector.

Weber and Hauer (2003) have found that Candian agricultural landowner could gain substantially as a result of climate change. By regressing per acre annual land rental on climate and other non climate variables, they found that Canadian agricultural will be benefited from climate change by a $\$ 5.24$ billion increase in annual GDP.

Polsky (2004) has discussed that Ricardian climate sensitivity analyses should employ spatial effects and temporal changes. He applied Ricardian Hedonic approach by taking per acre annual agricultural land price as dependent variable. The model used by Polsky reflected time specific contingencies as well as space characteristics. From the 
model came out the concept of spatial economics of a geographical variables i.e. per acre land price. The value of land will be determined not only by the local conditions but also by conditions of the geographical neighbours. Polsky (2004) had used six spatial econometric models to explore human-environment relationship associated with climate sensitivities had varied over space and time in the U.S Great Plains for the time period 1969-1992.

Lippert, Kirmly, and Aurbacher (2008) has applied Hedonic Land Climate Price Method/Ricadian Approach to evaluate the impact of climate change on Agricultural sector in Germany. Historic climate data for 1961-1990 in respect of land rental, utilisable agricultural area and share of grassland were used in the analysis. In order to make projections A1B scenario of IPCC was used. The result has shown significant dependencies between climate factors and land rental. Land rental is positively significant with rising temperature and precipitation. Projection for the years 2011-2040 showed that a moderate climate change (rise) could increase in land rental.

\section{CLIMATE CHANGE IN PAKISTAN}

The phenomenon of Greenhouse Gases (GHG) has been going on ever since the universe came into being. The Earth's average temperature is a cause and effect of Greenhouse Gases emission. The Industrial Revolution, anthropogenic activities namely, power generation from fossil fuels and deforestation activities have been continuously increasing the atmospheric concentration of GHGs beyond their natural limits. These have resulted in an enhanced greenhouse effect, vis-à-vis, an increase in global temperature. It will be worth mentioning that there is no country in the world which is immune to GHGs including Pakistan.

Pakistan vulnerability to climate change is comparatively more due to its warmer climate as it is situated in a region where the occurrence of temperature increases is expected to be higher than the global averages. Its land area is mostly arid and semi-arid. About 60 percent of the area receives less than $250 \mathrm{~mm}$ rainfall annually and 24 percent receives $250-500 \mathrm{~mm}$. Its rivers are predominantly fed by the Hindu Kush Karakoram-Himalayan glaciers which are reported to be receding quickly due to global warming. Pakistan economy is largely agrarian and hence highly sensitive to climate. Due to larger risk of variability in monsoon rains, floods

and extended droughts are experienced. Accounting for all these factors, the water security, the food security and energy security in Pakistan are under serious threat. [Task Force on Climate Change (2010)].

\subsection{Pakistan's Status as a GHG Emitter}

In the year 2008, Pakistan's total GHGs emission were 309 million tons (mt) of carbon dioxide $\left(\mathrm{CO}_{2}\right)$ equivalent, comprising about 54 percent $\mathrm{CO}_{2}, 36$ percent methane, 9 percent nitrous oxide and one percent other gases. The biggest contributor is the energy sector with 50 percent, followed by agricultural 39 percent, industrial processes 6 percent and other activities 5 percent [Task Force on Climate Change (2010)]. 
Table 1

Comparison of Different Countries on the Basis of Their Per Capita Energy Consumption, Per Capita $\mathrm{CO}_{2}$ Emission from Fuel Combustion and Ratio of $\mathrm{CO}_{2}$ Emission from Fuel Combustion to Energy Consumption (2004)

\begin{tabular}{lccc}
\hline Country/Region & $\begin{array}{c}\text { Per Capita Energy } \\
\text { Consumption } \\
\text { (toe/capita) }\end{array}$ & $\begin{array}{c}\text { Per Capita } \mathrm{CO}_{2} \\
\text { Emission }\left(\mathrm{tCO}_{2} /\right. \\
\text { capita) }\end{array}$ & $\begin{array}{c}\mathrm{CO}_{2} \text { Emission Per Unit } \\
\text { Energy Consumption } \\
\text { (tCO } / \text { toe) }\end{array}$ \\
\hline World & 1.77 & 4.18 & 2.37 \\
South Asia & 7.91 & 19.73 & 2.49 \\
OECD & 4.73 & 11.09 & 2.34 \\
China & 1.25 & 3.66 & 2.93 \\
India & 0.53 & 1.02 & 2.40 \\
Pakistan & 0.49 & 0.76 & 1.56 \\
Bangladesh & 0.16 & 0.24 & 1.47 \\
\hline
\end{tabular}

Source: Final Report, Task Force on Climate Change, 2010.

The total GHG emission of Pakistan in FY 1994, as reported in the Initial Communication (INC) to UNFCCC were 181.7 million tons of $\mathrm{CO}_{2}$ equivalent. These are estimated to have increased to 309.4 million tons of $\mathrm{CO}_{2}$ equivalent by 2008 . The sectoral breakup for the two years 1994 and 2008 are shown in Table 2.

Table 2

Inventories of Greenhouse Gases in 1994 and 2008

\begin{tabular}{|c|c|c|c|}
\hline Description & 1994 & 2008 & $\begin{array}{c}\text { AAGR } \\
(\%)\end{array}$ \\
\hline \multicolumn{4}{|l|}{ GHG Emission from All Sectors } \\
\hline $\begin{array}{l}\text { Total GHG emission (Million tones of } \mathrm{CO}_{2} \\
\text { equivalent) }\end{array}$ & 181.7 & 309.4 & 3.9 \\
\hline $\begin{array}{l}\text { Total GHG emission per capita (Kilogram of } \\
\mathrm{CO}_{2} \text { equivalent) }\end{array}$ & 1541 & 1922 & 1.6 \\
\hline $\begin{array}{l}\text { Total GHG emission per } 1000 \text { US\$ of year } 2008 \\
\text { (kilogram of } \mathrm{CO}_{2} \text { equivalent) }\end{array}$ & 2209 & 1942 & -0.9 \\
\hline \multicolumn{4}{|l|}{ GHG Emission from Fuel Sector Only } \\
\hline Total Emission GHG emission from Fuel & & & \\
\hline $\begin{array}{l}\text { Combustion Activities (million tons of } \mathrm{CO}_{2} \\
\text { equivalent) }\end{array}$ & 78.9 & 152.1 & 4.8 \\
\hline Total GHG emission per capita from Fuel & & & \\
\hline $\begin{array}{l}\text { Combustion Activities (kilogram of } \mathrm{CO}_{2} \\
\text { equivalent }\end{array}$ & 669 & 945 & 2.5 \\
\hline $\begin{array}{l}\text { Total GHG emission from Fuel Combustion } \\
\text { Activities per } 1000 \text { US\$ of year } 2008 \text { (kilogram } \\
\text { of } \mathrm{CO}_{2} \text { equivalent) }\end{array}$ & 959 & 955 & - \\
\hline \multicolumn{4}{|c|}{ Population Growth and Gross Domestic Product (GDP) } \\
\hline Population (Million) & 117.9 & 161.0 & 2.2 \\
\hline GDP (Billion US\$ in 2007-08 Prices) & 82.3 & 159.3 & 4.8 \\
\hline
\end{tabular}

Source: Final Report, Task Force on Climate Change, 2010. 


\subsection{Agriculture Sector in Pakistan: Current Status and Vulnerability}

Agriculture and livestock sector have been the mainstay of the Pakistan economy. It contributes 22 percent to gross domestic product (GDP), accounts for 60 percent of country's exports, provides livelihood to about 68 percent of the country's population living in rural areas, and employs 43 percent of the total labour force. Its foremost challenge is to provide adequate food for the population growing at 2 percent annually without irreversibly damaging fragile ecosystem. Being open to vagaries of nature, agricultural activities are highly vulnerable to climate change. A change in climate will have far reaching implications on food security of the country mainly through reduction in crop productivity and adverse impacts on livestock health, its productivity and reproducibility as well as due to an increase production losses caused by extreme events of floods, droughts and cyclones etc. [Task Force on Climate Change (2010)].

\section{THEORETICAL FRAMEWORK OF THE STUDY}

\subsection{Hedonic Price Approach}

Economic theory says that a consumer will buy different goods for obtaining utility. Hedonic approach has gone to suggest that it is not only a good or product per se but its characteristics that provide utility. Therefore, the total amount of utility a consumer derives from the purchase of a good or product is dependent upon the total amount of product characteristics. For equilibrium, the price paid by the consumer should be equal to the sum of product's characteristics marginal monetary values. The Hedonic pricing models were first introduced in economics in the late 1960s. Lancaster (1966), Dhrymes (1967), and Ladd and Suvannunt (1976) have contributed to development of the basic theoretical framework for Hedonic pricing of consumer goods characteristics. Rayner (1970) has further extended the basic theory to include brand names in addition to the quality characteristics. The theoretical framework of the basic Hedonic price model has been applied to deduce the Hedonic property value model, Hedonic wage model and agricultural land value model in the context of climate change.

The idea of Hedonic property value can be traced back to the classical work of Wallace (1926) and Hass (1922). Generally, the property value model has suggested that environmental attributes e.g. air and water quality affect the overall property prices. Hedonic relation has arisen due to heterogeneity in the quality attributes of different properties. Lancaster (1966), Rosen (1974), Maclennan (1977), Witt, Sumka and Erekson (1979), Awan, Odelling-Sme and Whitehead (1982) Goodman (1998) and Colwell and Dilmore (1999) have contributed in developing of theoretical framework of Hedonic property pricing models. The standard Hedonic price model is based on the analysis of a cross-section of housing price at a point in time. The repeated sales model is a variant of time of the Hedonic price model that exploits a time series of sale prices of a house which structural characteristics have not changed over time. Palmquist (1982) developed the repeated sales model which has simplified the specification and estimation as characteristics that do not change can be omitted from the regression equation.

Hedonic price model can be employed to measure the economic impact of climate change on agricultural sector. A Hedonic price model to determine the economic impact of climate change on agricultural sector refers to the willingness to 
pay to avoid a rise in temperature by investigation two or more agricultural lands that encounter the same climate factors as maximum, minimum temperatures and precipitations etc.

\subsection{Land Climate Hedonic Price Approach}

Rosen (1974) has suggested that Hedonic relation will arise due to the heterogeneity in quality of the attributes of the goods. Agricultural land prices are dependent upon factors that determine agricultural productivity i.e. climate (max, min temperatures, precipitations, solar radiation etc.), soil quality and slope (flat vs. hilly). [Kolstad (2000)]. Palmquist (1991) has opined that in agricultural sector, across different locations over time there generally have existed land price differentials, and the value of marginal changes in climate can be discerned from Hedonic land price analysis. In such a case, climate itself will become a choice variable. It can be safely presumed that long run cost minimising adaptation has already occurred.

Goulder and Pizer (2006) have opined that "applied to agricultural, the Hedonic approach has aimed to embrace a wider range of substitution options, employing crosssection data to examine how geographical, physical and climate variables have been related prices of agricultural land. On the assumption, that crops are chosen to maximise rents, the rents reflect the productivity of a given plot of land relative to marginal land, and prices are the present value of land rents. The effects of climate change variables on land prices are an indicator of their impact on productivity after crop substitution is allowed for.

Amiraslany (2010) has suggested that the land climate Hedonic price model can be used to estimate the impact of climatic, socio-economic and geographical variables in valuating agricultural land which allows measuring of the marginal contribution of the attributes in order to capitalise the land value.

\subsection{Assumptions of Land Climate Hedonic Pricing Method}

The Hedonic agricultural price model of climate change has been based on the following assumptions [Maddison (2000)].

- There is perfect competition in land market.

- Land values have attained the long run equilibrium associated with each region's climate.

- There is uniform market for agricultural lands.

- There is no relocation cost existing in the market. (it implies that zero transaction and moving cost with flexible prices).

- There is continuous trade-off among all characteristics.

- Agro-technologies which respond to climate change are accessible to all farmers at any given point in time.

The assumption of perfect competition implies that the information is perfect and all economic agents have free access to it. Moreover, all economic agents are rational and adapt according to the information. 


\subsection{Functional Form of the Model}

The land values depend upon climate (maximum, minimum temperatures, precipitations, solar radiation, etc), slope (hilly vs. flat) and tendency to flood. These factors will determine productivity which determines prices of a piece of land. Another factor that could contribute to land price difference but not agricultural productivity is proximity to urban areas etc. Mendelsohn, et al. (1994) applied Hedonic price model to link land value to land characteristics including climate factors The Hedonic equation to estimate of the effects of climate change is given as;

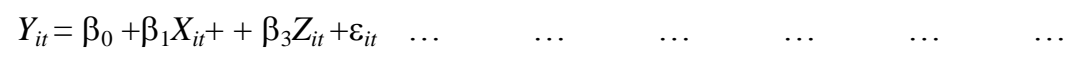

Here,

$Y_{i t}=$ per acre agricultural land price in $i$ th district for time period $t$.

$\beta_{0}=$ constant term

$X_{i t}=$ vector of all climate variables (average maximum, minimum temperatures and precipitations) in $i$ th district for time period $t$.

$Z_{i t}=$ vector of all non climate variables (population density, per capita income and area under cultivation etc.) for $i$ th district for time period $t$.

$\varepsilon_{i t}=$ stochastic error term

\subsection{Choice of the Dependent Variable}

Both the rental prices of land and asset prices of land can be taken as dependent variable. The land rental price is the price of renting the land for a given short period of time .On the other hand, the asset price of land is the price of taking time title to perpetuity [Kolstad (2000)].

\subsection{Structure of the Data Used in the Model}

In most of the studies for measuring the economic impact of climate change on agricultural sector have used spatial Hedonic price model across different location that relates to a single year. Rarely are available, the time series data on sales or rental prices for different types of agricultural lands. These data can be used to used to develop a repeated sales type Hedonic price model. Since some structural attributes of agricultural land do not vary over time or have negligible variation over time like soil characteristics. The repeated sales model makes the analysis simple as all attributes that are not change over time can be eliminated. Panel data with same cross-section units (e.g., districts or counties) over a given period of time can also be used to capture the economic impact of climate change. Strengths of panel data are that it can measure regional scale climate sensitivities, allowing for spatial effects and temporal change.

\section{DATA AND DESCRIPTION OF VARIABLES}

\subsection{Study Area}

The major contributor to Pakistan GDP is the agricultural sector. On farm practices have been undertaken under different climate conditions, special biophysical and socioeconomic conditions prevalent in rural areas of Punjab province. These being the reasons 
for selecting the Punjab agricultural sector for the study. The total land area of Punjab province is 20.63 million hectares which is about 26 percent of the total area of Pakistan. The cultivated area of Punjab is 12.51 million hectares, or 67 percent of total cultivated area of Pakistan. As stated earlier, in 2007-08 Punjab share in Pakistan's agricultural production of major crops was wheat 74.5 percent, rice 59.1, percent, gram 81.7 percent, jawar 61.2 percent, maize 74.5 percent, Bajra 73.4 percent, cotton 77.8 percent, sugarcane 63.1 percent, barley 33.3 percent, rapeseed and mustard 58.5 percent. In respect of the major fruits, Punjab share in the overall country's production was mango 78.3 percent, banana 6.3 percent, citrus 96.7 percent, guava 78.3 percent, dates 7.9 percent and apple 0.7 percent [Punjab Development Statistics (2009)].

The Indus, and its tributaries, Jhelum and Chanab are the main rivers from which canals have been taken out to supply water for irrigation in Punjab. The requirements of water for cultivation are also met from tubewells. For carrying out the study, the data of eleven districts which are also representative of different climate conditions have been used. The reason for selection of these districts namely, Lahore, Faisalabad, Sargodha, Sialkot in central region; Jhelum, Rawalpindi, and Mianwali, in northern regions; Multan, Bahawalpur, Bahawalnagar, and Rahim Yar Khan in southern region was that these places had climate observation stations.

Table 3

Share of Agricultural GDP of the Punjab in Agricultural GDP of Pakistan (at Constant Factor Cost of 1999-00)

\begin{tabular}{|c|c|c|c|c|c|c|c|}
\hline \multirow[b]{2}{*}{ Sr. No. } & \multirow{2}{*}{$\begin{array}{l}\text { Agricultural } \\
\text { Production } \\
\text { Sector }\end{array}$} & \multicolumn{3}{|c|}{ 2008-09 } & \multicolumn{3}{|c|}{ 2009-10 } \\
\hline & & Pakistan & Punjab & Percent Share & Pakistan & Punjab & Percent Share \\
\hline 01 & Major Crops & 1195031 & 635444 & 53.2 & 1218873 & 646281 & 53.0 \\
\hline 02 & Minor Crops & 136601 & 287347 & 59.7 & 135008 & 84641 & 62.7 \\
\hline 03 & Live Stock & 622531 & 260344 & 41.8 & 648106 & 268327 & 41.4 \\
\hline 04 & Fishing & 21319 & 5003 & 23.5 & 21626 & 5044 & 23.3 \\
\hline 05 & Forestry & 14094 & 1202 & 8.5 & 14404 & 1484 & 10.3 \\
\hline
\end{tabular}

\subsection{Climate of Punjab Province}

The characteristics and climate data of Punjab province have already been elicited in Chapter Four. In brief, there has occurred a rise in maximum temperature in Punjab province but the rise is not significant. There has also been observed a significant rise in the minimum temperature all across the province. As reported in Climate Change Indicators of Pakistan, 2009 Punjab, as a whole, has experienced a significant rise in precipitation.

\subsection{Definition of Variables}

The unit of spatial analysis for the study are the districts of Punjab. The fundamental agent in land use is the farmer or farmland. The dependent and independent variables in the study are defined in Table 4 . The independent variables are categorised into two groups: climate and non-climate variables. The elaboration of these variables are as given under: 
Table 4

Description of Variables

\begin{tabular}{|c|c|c|c|}
\hline Variable & Title & Definition & Source of Data \\
\hline $\begin{array}{l}\text { Dependent } \\
\text { Variable }\end{array}$ & Lprice & $\begin{array}{l}\text { Average Annual market sale price of agricultural } \\
\text { land (Pak RS/acre) at district level. }\end{array}$ & $\begin{array}{l}\text { Mutation registers of land } \\
\text { price records. Land } \\
\text { Revenue Department, } \\
\text { Govt of Punjab. (1970- } \\
2009 \text { ) }\end{array}$ \\
\hline \multicolumn{4}{|c|}{$\begin{array}{l}\text { Independent Non-Climate } \\
\text { Variables }\end{array}$} \\
\hline $\begin{array}{l}\text { Area under } \\
\text { Cultivation }\end{array}$ & AUC & $\begin{array}{l}\text { Per year use of land for agricultural purposes } \\
\text { including land under crops, vegetables, orchards } \\
\text { etc. The unit of analysis is Thousand Hectares at } \\
\text { the districts Level. }\end{array}$ & $\begin{array}{l}\text { Punjab Development } \\
\text { Statistics(1970-2010) }\end{array}$ \\
\hline $\begin{array}{l}\text { Population } \\
\text { Density }\end{array}$ & POPD & $\begin{array}{l}\text { The total number of people living per square } \\
\text { kilometre at district level. }\end{array}$ & $\begin{array}{l}\text { Punjab Development } \\
\text { Statistics }(1970-2010)\end{array}$ \\
\hline $\begin{array}{l}\text { Per Capita } \\
\text { Income }\end{array}$ & YPC & National per capita income measured in Pak Rs. & $\begin{array}{l}\text { Economic Survey of } \\
\text { Pakistan (1970-2009) }\end{array}$ \\
\hline \multirow{8}{*}{$\begin{array}{l}\text { Independent } \\
\text { Variables }\end{array}$} & Climate & & \\
\hline & Variables & & \\
\hline & RABIPPT & $\begin{array}{l}\text { Precipitation(millimetres }=m m \text { ) normal mean for } \\
\text { the Rabi months(October }- \text { March) }\end{array}$ & $\begin{array}{l}\text { Pakistan Meteorological } \\
\text { Department(1970-2009) }\end{array}$ \\
\hline & KHARIFPPT & $\begin{array}{l}\text { Precipitation (millimetres) normal mean for the } \\
\text { Kharif months(April -September) }\end{array}$ & $\begin{array}{l}\text { Pakistan Meteorological } \\
\text { Department(1970-2009) }\end{array}$ \\
\hline & MINTMRABI & $\begin{array}{l}\text { Minimum temperature }\left(\text { Degree } \text { Celsius }={ }^{0} \mathrm{C}\right) \\
\text { normal mean for the Rabi months }(\text { October - } \\
\text { March) }\end{array}$ & $\begin{array}{l}\text { Pakistan Meteorological } \\
\text { Department(1970-2009) }\end{array}$ \\
\hline & MINTMKAHRIF & $\begin{array}{l}\text { Minimum temperature(Degree Celsius }={ }^{0} \mathrm{C} \text { ) } \\
\text { normal mean for the Kharif months(April - } \\
\text { September) }\end{array}$ & $\begin{array}{l}\text { Pakistan Meteorological } \\
\text { Department(1970-2009) }\end{array}$ \\
\hline & MAXTMRABI & $\begin{array}{l}\text { Maximum temperature }\left(\text { Degree Celsius }={ }^{0} \mathrm{C}\right) \\
\text { normal mean for the Rabi months }(\text { October - } \\
\text { March }\end{array}$ & $\begin{array}{l}\text { Pakistan Meteorological } \\
\text { Department(1970-2009) }\end{array}$ \\
\hline & MAXTMKHARIF & $\begin{array}{l}\text { Maximum temperature (Degree Celsius }={ }^{0} \mathrm{C} \text { ) } \\
\text { normal mean for the Kharif months(April - } \\
\text { September) }\end{array}$ & $\begin{array}{l}\text { Pakistan Meteorological } \\
\text { Department(1970-2009) }\end{array}$ \\
\hline
\end{tabular}

\subsection{Dependent Variable}

The dependent variable in the study is the average sale price per acre (Pak Rs/acre) annually, which is deemed to be consistent with Ricardian Approach based on Land Climate Hedonic Pricing. The rationale for using asset price of land imbibes perpetuity as well as long-term variations are deemed to be in-built.

It is documented in final report of Task Force, Planning Commission $\mathrm{GoP}^{6}$ on Climate Change that there is a dire need to quantify the impact of climate change on different sectors of the economy for planning and policy making. The report has also noted that it is not easy to assess the economic impact of climate change on different sectors of the economy. But it is of very crucial importance for national planners and policymakers to develop and shape the country's development plans in the most optimal manner within the constraints of limited available resources. Viewed in this perspective, 
the study in hand is the first effort to quantify the impact of climate change on agricultural sector. It was very tiring, time consuming and enduring drill to collect data of dependent variable. At the district level, town/village/mouza were selected to obtain the average price per acre of agricultural land in order to capture the impact of climate change. Town/village/mouza is the unit which is agricultural land area since 1970 to date. The farm land was not to be situated on the road side but have an easy access to agricultural markets. The annual average sale price of agricultural land was taken from the mutation registers maintained by Patwaris. To select a unit of analysis, tehsildars and patwaris of the respective districts were interviewed. The selected town/mouza/village per acre average agricultural land price was assumed to be representative of all normal agricultural lands in the respective districts. The same method was adopted to collect land price data for the eleven districts across Punjab province.

\subsection{Independent Climate Variables}

There are two crop sowing and harvesting seasons in Punjab, Kharif season from April to September and Rabi season from October to March. Climate variables in the study are the yearly Kharif and Rabi months mean data from 1970 to 2009.

Kharif crops are rice, sugarcane, cotton (American), cotton (Desi), jowar, bajra, maize, moong, mash, til, gowara seed, fodder, vegetables and orchards etc. Rabi crops are wheat, gram, barely, masoor, peas, rape and mustard, fodder, vegetables, tobacco, and orchards etc.

Mean of minimum temperature for Kharif and Rabi season, mean of maximum temperature for Kharif and Rabi season measured in degree Celsius $\left({ }^{\circ} \mathrm{C}\right)$, while mean of precipitation for Kharif and Rabi season measured in millimeters have been taken as climate variables. The data were obtained from Pakistan Meteorological Department GoP, Islamabad for the eleven districts for the period 1970-2009. The missing values were assessed by taking three years moving average.

\subsection{Independent Variables (Non-climate)}

The independent variables in the land climate Hedonic model used in the present research study have been divided into two categories i.e., non climate and climate variables. For non climate variables, population density i.e., persons per $\mathrm{km}^{2}$ (POPD) and per capita income (YPC) are specified to control the competition for non agricultural land uses.

In Pakistan, four census of population have been conducted. The first census was conducted as back as 1951 and the most recent in 1998. The estimate of yearwise population growth rate at the district level in 1961, 1972, 1981 and 1998 were 2.7 percent, 3.41 percent, 2.74 percent and 2.64 percent respectively. These growth rates were used in the study. The data of population projection from 1999-2009 are taken from the Punjab Bureau of Statistics, Lahore.

The area under cultivation (AUC) is also included as an independent variable. The rationale for taking the area under cultivation as an independent variable is that it covers land use for growing all kinds of crops and orchards as well as current fallow.

The data of population density and area under cultivation were taken from different issues of Punjab Development Statistics, Punjab Bureau of Statistics. The data of per capita income was taken from different issues of Pakistan Economic Survey. 
Table 5

Descriptive Statistics

\begin{tabular}{|c|c|c|c|c|c|c|c|}
\hline Sr. & & & Standard & & & & Cross \\
\hline No & Variable & Mean & Deviation & Min & Max & Observations & Sections \\
\hline 01 & Land Price (Rs) & $209,756.20$ & $427,963.2$ & 202.4 & 5333333 & 440 & 11 \\
\hline 02 & Income Per Capita (Rs) & 456.67 & 140.88 & 220 & 800 & 440 & 11 \\
\hline 03 & Population Density & 627.01 & 832.45 & 40.46 & 4775.39 & 440 & 11 \\
\hline 04 & Area under cultivation & 543.48 & 449.93 & 78 & 2926 & 440 & 11 \\
\hline 05 & Rabi Precipitation & 21.82 & 18.1 & 0 & 91.06 & 440 & 11 \\
\hline 06 & Rabi Precipitation Square & 803.28 & 1279.015 & 0 & 8293.14 & 440 & 11 \\
\hline 07 & Kharif Precipitation & 68.50 & 53.61 & 0.08 & 294.58 & 440 & 11 \\
\hline 08 & Kharif Precipitation Square & 7560.95 & 11139.72 & 0.01 & 86779.34 & 440 & 11 \\
\hline 09 & Rabi Maximum Temperature & 26.14 & 2.24 & 19.70 & 32.90 & 440 & 11 \\
\hline 10 & Rabi Maximum Temperature Square & 688.77 & 120.14 & 388.09 & 1082.410 & 440 & 11 \\
\hline 11 & Kharif Maximum Temperature & 37.16 & 1.554 & 32 & 42 & 440 & 11 \\
\hline 12 & Kharif Maximum Temperature Square & 1383.90 & 122.83 & 1062.70 & 1062.70 & 440 & 11 \\
\hline 13 & Rabi Minimum Temperature & 12.16 & 5.299 & 6.10 & 30.32 & 440 & 11 \\
\hline 14 & Rabi Minimum Temperature Square & 175.92 & 185.99 & 37.21 & 919.30 & 440 & 11 \\
\hline 15 & Kharif Minimum Temperature & 23.33 & 4.618 & 9.78 & 37.29 & 440 & 11 \\
\hline 16 & Kharif Minimum Temperature Square & 565.69 & 201,05 & 95.71 & 1390.63 & 440 & 11 \\
\hline
\end{tabular}

\subsection{The Basics of Panel Model}

Given herein is the econometric framework used in measuring the economic impact of climate change on Punjab agricultural sector. The model specification has involved regressing per acre land price over climate variables for the years 1970-2009 while controlling the other non climate variables affecting agricultural land. The data is pooled for thirty years for eleven districts of Punjab. District level per acre agricultural land price was regressed on climate, non climate (control) variables to estimate the best use value function for Punjab agricultural sector. The econometric methodology is defined as Hedonic approach and one way panel fixed effect approach.

\subsection{The Panel Fixed Effect Approach}

A panel is a cross-section (firms, individuals, group of people) which is surveyed over a certain period of time span. Panel data sets, the data sets on different crosssections over a certain period of time, help the researcher in modelling difference of attributes across cross section. Heterogeneity across units (cross-sections) is an integral part of the panel data analysis [Greene (2003)].

The reason to include place (district) fixed effects is that district fixed effects can absorb unobserved time invariant determinants of the dependent variable.

When Cross section fixed effect is applied, model have constant slopes but intercept differ according to time. The source of variation in the intercept is some unobserved attributes (i.e. preference for agricultural occupations in specific districts agricultural practices etc.). These unobserved attributes vary from one district to the other but are constant over time [Stock and Watson (2003)].

The Standard Model is:

$$
Y_{i t}=\beta_{0}+\beta_{1} C_{i t}+\beta_{2} C_{i t}^{2}+\beta_{3} Z_{i t}+\varepsilon_{i t} \quad \ldots \quad \ldots \quad \ldots \quad \ldots \quad \ldots \quad \ldots
$$

Here,

$Y_{i t}=$ per acre agricultural land price in district over time period $t$. 
$\alpha_{0}=$ constant

$C_{i t}=$ vector of climate variables in $i$ th district for time period $t$.

$C_{i t}^{2}=$ vector of climate variables in quadratic form in $i$ th distract $t$ for time period $t$.

$Z_{i t}=$ vector of non climate variables (population density, per capita income and area under cultivation) for $i$ th district for time period $t$.

$\varepsilon_{i t}=$ stochastic error term.

To show one way fixed effect, assume that $C_{i t}, C_{i t}{ }^{2}$ and $Z_{i t}$ all are include in the $X_{i t}$ matrix.

Then

$$
y_{i t}=\eta_{\text {districts }}+\beta X_{i t}+\mu+\varepsilon_{i t}
$$

Then, the one way (cross-section) fixed effect estimator for $\alpha_{0}, \beta_{1}, \beta_{2}$ and $\beta_{3}$ in (5.1) is $b$ as follows [Amiraslany (2010)].

$$
\begin{aligned}
& \mathrm{b}=\left[\sum_{i=1}^{40} \sum_{t=1}^{40}\left(x_{i t}-\bar{x}_{i}, \bar{x}_{i}+\bar{x}\right)\left(x_{i t}-\bar{x}_{i}, \bar{x}_{{ }_{i}}+\bar{x}\right)^{\prime}\right]- \\
& { }^{1} \mathrm{x}=\left[\sum_{i=1}^{40} \sum_{t=1}^{40}\left(x_{i t}-\bar{x}_{i}, \bar{x}_{i}+\bar{x}\right)\left(y_{i t}-\bar{y}_{i}, \bar{y}_{{ }_{i}}+\bar{y}\right)^{\prime}\right]^{-1}
\end{aligned}
$$

Now, the regression constant term is:

$$
\hat{\mu}=\bar{y}-\overline{\overline{x^{\prime}}} b
$$

and fixed effect one-way estimator for district fixed effects is:

$$
\eta_{\text {districts }}=\left(\bar{y}_{i,}-\bar{y}\right)-\left(\bar{x}_{i,}+\bar{x}\right)^{\prime} b
$$

Here the bar symbols shows the average in the above formulas.

\subsection{Econometric Estimation}

An econometric model is an important tool for the researcher to part and determine the influence of several explanatory variables on a dependent variable. The important issue is that climate variables and squared terms of them inherently have potential multicolliniarity. Kaufman (1998) had suggested that regressing models with undemeaned (when data are not subtracted from their mean) climate variables lead to frequent switching of the parameters estimates and may cause large marginal effects. According to Stock and Watson (2003) regression softwares will compute the fixed effects in two steps. First, the entity specific average is subtracted from each variable. Second, the regression is estimated using "entity-demeaned" variables. This problem is tackled as E.views software package is used for regression estimation, and all climate variables have been demeaned (subtracting all values from their mean) to prevent the problem of multicolliniarity in the estimated model.

Feasible Generalised Least Square (FGLS) technique with cross section SUR has been used to estimate the panel regression model. In the study in hand, the following aspects have been considered to determine the robustness of the model. 
- The significance level of each explanatory variable will be determined by the coefficient t-statistics.

- The fit of overall model is determined by the F-statistics and R-squared values.

- Individual explanatory variables' direction of influence on the dependent variable and its consistency with literature and Pakistan climate conditions will be checked.

The description of Panel regression methodology with cross-section fixed effects for estimation has been given in chapter five.

Based upon the methodology, the land climate pricing model has estimated economic impact of climate change normals on the agricultural sector in respect of eleven districts in Punjab for the period 1970-2009. The econometric approach applied to assess the climate impact is FGLS (cross-section Seemingly Unrelated Regression) with oneway fixed effect panel model specification with the districts fixed effects. The chapter is designed to discuss the estimated parameters and also comments on the results in order to link them with chapter seven.

\section{RESULTS}

\subsection{Parameters Estimated}

The study has taken into account forty points of time and eleven districts of Punjab. The panel fixed effect model for cross section can capture more information on heterogeneity among districts. Feasible Generalised Least Square (FGLS) with cross section SUR technique has been used to run the panel regression.

Table 6 shows the FGLS (cross section SUR) model results of all the independent, dependent (climate and non climate), t-statistics R-squared, F-test and other relevant statistics. For estimation, quadratic forms of climate variables have also been considered with linear form. Taking quadratic form is consistent with the literature ${ }^{7}$. Quadratic forms were taken into account to capture the possibilities of nonlinearities in climate sensitivities. The linear term of climate variables show the marginal value of climate at the land price mean, while the quadratic terms show the nature of the relationship among climate variables and land value as given under:

- A positive coefficient shows a U shape while negative coefficient depicts a hill shape $(\cap)$ relationship among climate variables and land values.

- U shape relationship indicates that land prices will decrease with increase in climate variables to a certain point (minimum of $\mathrm{U}$ ), then both land prices and climate variables will increase.

- Hill shape $(\cap)$ relationship indicates that as climate variables increase the land value also increases to a certain degree (maximum of $\cap$ ), departure from this point will lead to reduction in land values with an increase in climate variables.

As noted from the result, $\mathrm{C}$ being the constant term, in fixed effects model; the constant term contained all fixed effects. Table 6 Shows Panel Estimation Results: with FGLS (cross section SUR) technique.

${ }^{7}$ See Section 2. 
Table 6

Panel Estimation Results: FGLS (Cross Section SUR)

\begin{tabular}{|c|c|c|}
\hline Variables & & Coefficients \\
\hline \multicolumn{3}{|c|}{ Climate } \\
\hline & Rabi precipitation & $-877.11 * *$ \\
\hline & Rabi precipitation Squared & $8.50 * * *$ \\
\hline & Kahrif precipitation & $168.92 * * *$ \\
\hline & Kharif precipitation Squared & $-1.17 * * *$ \\
\hline & Minimum Rabi Temperature & $-3868.66 * * * *$ \\
\hline & Minimum Rabi Temperature Squared & $162.93 * * *$ \\
\hline & Minimum Kharif Temperature & $6088.82 * * * *$ \\
\hline & Minimum Kharif Temperature Squared & $-188.81 * * *$ \\
\hline & Maximum Rabi Temperature & $26085.60 * * *$ \\
\hline & Maximum Rabi Temperature Squared & $-438.47 * * *$ \\
\hline & Maximum Kharif Temperature & -3003.86 \\
\hline & Maximum Kharif Temperature Squared & 13.03 \\
\hline \multicolumn{3}{|c|}{ Non-climate (control) } \\
\hline & Population Density & $30.84 *$ \\
\hline & Area under Cultivation & 1.058 \\
\hline & Income Per Capita & $54.79 *$ \\
\hline & Constant & -294035.2 \\
\hline & LPRICE(-1), Lag of Dependent Variable & $0.915^{*}$ \\
\hline \multicolumn{3}{|c|}{ District Fixed Effects } \\
\hline & Bhawalpur & -52453.99 \\
\hline & Bhawalnagar & 19507.44 \\
\hline & Faisalabad & 35039.85 \\
\hline & Rawalpindi & 124067.6 \\
\hline & Jehulm & 32901.58 \\
\hline & Lahore & -64938.94 \\
\hline & Mianwali & -15004.54 \\
\hline & Multan & -22576.11 \\
\hline & Rahim Yar Khan & -38415.25 \\
\hline & Sargodha & 17444.15 \\
\hline & Sialkot & 3443.14 \\
\hline & $\mathrm{R}^{2}$ & 0.93 \\
\hline & Adjusted $\mathrm{R}^{2}$ & 0.92 \\
\hline & F-statistics & 215.56 \\
\hline & Akaike Information Criterion & 24.99 \\
\hline & Schwarz Criterion & 25.09 \\
\hline & Durban-Watson Statistics & 2.06 \\
\hline
\end{tabular}

*Denotes 1 percent, $* * 5$ percent, ${ }^{* * *} 10$ percent, and $* * * * 15$ percent. 


\subsection{Climate Variables}

Precipitation has been a very important variable in agricultural sector of Punjab.

Mean Rabi precipitation has shown a U shape relationship (U) with land prices. It has revealed that increase in precipitation in Rabi season will decrease land price. Precipitation is significant at 5 percent level of significance.

Mean Kharif precipitation also has significant relationship with land values. The relationship is of hill shaped $(\cap)$ relationship. It has revealed that with an increase in Kharif precipitation, land prices will increase. The results have been in accordance with expectations. Kharif crops have been sensitive to more precipitations. Especially, rice a major Kharif crop is water demanding crop.

Mean minimum Rabi temperature had a significant relationship with land prices. It had shown U shape relationship with land prices. With an increase in mean minimum Rabi temperature, land price will decrease. It was significant at 10 percent level of significance.

Mean minimum Kharif temperature has a significant hill shaped $(\cap)$ relationship with land prices. It indicates that with increase in mean minimum Kharif temperature, land prices will also increase. It is significant at 25 percent level of significance.

Mean maximum Rabi temperature has a significant hill shape $(\cap)$ relationship with land prices. It reveals that with increase in mean maximum Rabi temperature, land prices will also increase. It was significant at 10 percent level of significance.

Mean maximum Kharif temperature has $\mathrm{U}$ shape relationship with land prices, but this relationship is not found to be significant.

Table 7

Comparison of Kharif and Rabi Climate Variables and Relationship with Land Price Dependent Variable

\begin{tabular}{ll}
\hline \multicolumn{1}{c}{ Kharif } & \multicolumn{1}{c}{ Rabi } \\
\hline Precipitation had significant hill $(\cap)$ & Precipitation had significant $U$ \\
relationship with land prices & relationship with land prices \\
Mean minimum temperature observed & Mean minimum temperature had \\
significant hill shape $(\cap)$ relationship & significant U shape relationship with land \\
with land prices. & prices \\
Mean Maximum temperature had & Mean Maximum temperature had \\
insignificant U shape relationship with & significant hill shape $(\cap)$ relationship \\
land prices. & with land prices. \\
\hline
\end{tabular}

Rasul, et al. (2009) had found that in Punjab minimum temperature had increased significantly over the period 1960-2007. Mean minimum temperature of both Kharif and Rabi has significant relationship with land prices in the current study also. Precipitation had found to have increased during 1960-2007 in Punjab [Rasul, et al. (2009)]. FGLS model results have confirmed the fact by showing significant relationship of precipitation with land prices both in Kharif and Rabi season.

It has also been found that in Punjab maximum temperature had not increased significantly during 1960-2007 [Rasul, et al. (2009)]. 
One important parameter that Rasul (2009) had taken into account was the annual mean minimum, maximum and precipitation. Study in hand required to quantify the economic impact of climate change on agricultural sector, therefore, mean maximum, minimum and precipitation split the annual climate variables into two sowing and harvesting seasons i.e. Kharif and Rabi. FGLS model results show that mean maximum temperature do not have significant relationship with land prices, while mean of maximum Rabi temperature has hill shaped $(\cap)$ relationship with land prices. The study on climate change and wheat production by Global Change Impact Study Centre (2010), had brought that wheat production will increase with the increase in temperature. Wheat is Rabi crop, mean maximum Rabi temperature has significant hill shape $(\cap)$ relationship with land prices in study in hand. It can safely be deduced that with increase in Rabi mean maximum temperature, wheat production will increase.

Direct interpretation of the regression coefficients within the land climate Hedonic pricing/Ricardian approach is not tenable for specific impact on crop yield. However, based upon the model results, direction of the signs of the coefficients and nature of the relationship, educated speculations to some extent can be made.

Kharif precipitation has hill shape $(\cap)$ relationship with land values. As moisture soil will increase crop production. Rabi precipitation is not as much demanding as of Kahrifs', Rabi precipitation has negatively related to land values, it can be speculated that increase in Rabi mean precipitation will decrease crop yield of wheat. On the other hand, mean maximum Rabi temperature is significant, has positive sign which shows increase in mean maximum temperature will increase crop yield as wheat needs heat for maturation. The results have indicated that Rabi season is winter and partly spring low precipitation and high temperature will tend to reduce risks of fog and frost in Punjab. Both low precipitation and high temperatures are conducive for crop maturation.

\subsection{Marginal Climate Impacts}

In Section 6.3, there is interpretation of linear coefficients (constant slopes) and squared coefficients (non linear slopes which are a function of climate variables). It is not possible to capture the magnitude of the impact of climate variables with linear and squared coefficients individually. Marginal climate impact (MCI) for each set of climate variables (linear and squared coefficients) jointly has been calculated to capture the magnitude of the impact of climate variables on agricultural land price. Recalling from discussion 6.2, if land prices are expressed in quadratic function of climate variables, the partial derivative of the dependent variable land price (LPRICE) with respect to climate variables would be

DLPrice/OClimate $=\beta_{2}+\beta_{3}$ Climate $\quad \ldots \quad \ldots \quad \ldots \quad \ldots$

By taking the mean of both sides

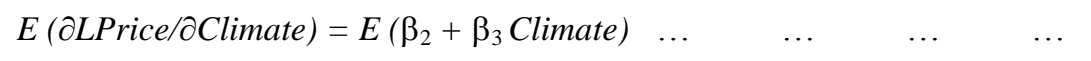

Which is (Equation 6.2) is MCI for any climate variable. Marginal climate impact is the magnitude of change in any climate variable. In this section, marginal climate impacts represent the change in Pak Rs/acre of agricultural land prices per ${ }^{0} \mathrm{C}$ or $\mathrm{mm} /$ Kharif and marginal climate impact represent the change in Pak Rs/acre of 
agricultural land prices per ${ }^{0} \mathrm{C}$ or $\mathrm{mm} /$ Rabi climate for agricultural land in the Punjab province. Equation 6.2 can be calculated based upon the numbers from the estimation results. It can be tested as a restriction for FGLS (cross section SUR) model. To investigate the level of significance of estimated marginal climate impact, F-test is being run [Amiraslany (2010)]. The significance of F-test also checked. Marginal Climate impacts of all climate variables are presented in Table 8.

Table 8

Marginal Climate Impacts

\begin{tabular}{lccccc}
\hline Variables & $\beta_{2}$ & $\beta_{3}$ & SD & MCI & F.statistic \\
\hline Rabi Precipitation & -8.77 .11 & 8.5033 & 313.45 & $-860.10^{*}$ & 7.59 \\
Kharif Precipitation & 168.92 & -1.171 & 97.34 & $166.577^{* *}$ & 2.92 \\
Minimum Rabi Temperature & -3868.66 & 162.93 & 2888.460 & -3542.79 & 1.50 \\
Minimum Kharif Temperature & 6088.823 & -188.81 & 5090.83 & 5711.20 & 1.258 \\
Maximum Rabi Temperature & 26085.60 & -438.4713 & 146557.29 & $25208.66^{* *}$ & 2.957 \\
Maximum Kharif Temperature & -3003.86 & 13.03 & 61709.92 & -2977.78 & 0.0023 \\
\hline
\end{tabular}

*Denotes significant at 5 percent, and **Denotes significance at 10 percent level.

The MCI results show that with an increase in precipitation of $1 \mathrm{~mm}$ in Rabi season, agricultural land price will decrease, on average, by 860 Pak Rs per acre in Rabi season, while the same increase (1 mm precipitation) in Kharif season will bring increase in agricultural land price, on average, by 166.58 Pak Rs per acre in Kharif season. The resulted signs of coefficients are in according to expectations. As stated earlier, Kharif crops (e.g. rice) are more water demanding as compare to Kharif crops. Therefore, an increase in precipitation Kharif will lead to an increase in land prices.

On the other hand, MCI analysis of maximum Rabi temperature shows that with a $1{ }^{0} \mathrm{C}$ increase in maximum temperature, agricultural land prices, on average, will increase by 25208.66 Pak Rs in Rabi season.

The results and expected signs are in accordance with expectations. One major Rabi crops is wheat, which needs much warmer climate for maturation.

The expected signs and direction of relationship of maximum Kharif temperature, minimum Rabi and Kharif temperature are according to expectations, but marginal impacts of these climate variables are not significant. It is important to recognise that these results can be interpreted only with educated speculations for agricultural yield and crop productivity. As only land price might not reflect the agricultural yield and crops productivity. There are some other regional differences (non climate and non agricultural) that might affect the land prices also. Irrigation, soil fertility etc. are some of those factors that directly and indirectly might affect the land prices.

\subsection{Non-climate (Control) Variables}

As stated earlier, that some factors other than climate have been considered important in influencing the land prices. The practice of using control variables is consistent with other land Climate Hedonic Pricing/ Ricardian studies. In the study in hand, one different variable is used that is the area under cultivation ( 000 hectares) at the district level. The rationale for which is that if Rabi is getting warmer and precipitation is decreasing, some uncultivated land (marginal land) can be taken under cultivation. It also 
shows that soil moisture and other environmental conditions (e.g. low risk of frost and fog) are suitable to take marginal land under cultivation. The year wise values of area under cultivation for crops and orchards were taken in 000 hectares at the district level. Population density and per capita income were also included as control variables to avoid any misspecification error (omitted variable bias).

The parameter of population density is positive and strongly significant with land prices. It has revealed that agricultural land prices will rise with rise in population. It also has revealed that land is a fixed factor of production, as population increases, demand for food grains rises, and demand for agricultural land also rises. Therefore, land prices will rise with rise in population. Per capita income shows the purchasing power of people. Per capita income has positive sign and significant relationship with land prices. It shows that rise in per capita income will lead to rise in land prices.

Area under cultivation coefficient has positive sign but is not significant. It shows that any change in hectares of area under cultivation has no influence on land prices.

\subsection{Districts Fixed Effects}

The concept of including districts fixed effects has been presented in the chapter five. The district fixed effects can absorb unobserved time invariant determinants of land prices. The negative district coefficients show lower land values as compared to the positive district coefficients. The heterogeneity among the co-efficient of land values under fixed effects is due to unobserved factors. The unobserved and missing factors such irrigation, fertility of land etc. are not included in the model.

One very interesting result is the fixed negative effect coefficient for Lahore district, which is the provincial headquarter and centre of education, cultural, business and trade activities, The reason for which can be traced rapid urbanisation (unobserved) might be one reason. In Lahore, Most of agricultural land has been turned into residential housing colonies to meet the ever rising demand of houses.

\subsection{Overall Model Results}

$\mathrm{R}$-square value is 0.93 . It shows that 93 percent variation in the dependent variable is explained by explanatory variables (climate and non climate). F-statistic shows that joint significance of explanatory variables with dependent variable average agricultural per acre agricultural land price is highly significant. Different specifications of the model are estimated and the best model is reported. The FGLS estimation technique is used for the estimation of fixed effect model which is selected on the basis of minimum Schwarz and Akaike information criteria. As it was expected, the presence of autocorrelation and heteroscedasticity problems FGLS technique is used to take care of these problems. One lag of dependent variable is also used to capture inertia in the land prices.

\section{CONCLUSION AND POLICY RECOMMENDATION}

The objective of the study was quantification of impacts of change in climate normals to have a variable and sustainable development of agricultural sector both at the regional and country level. In this direction the study has gone to confirm the premises that climate change impinches considerably agricultural production and also price of 
agricultural land. In other words, if there is a decrease/increase in value of agricultural land due to climate change.

One of other distinct features inducted in the study are inclusion of Kharif and Rabi climate variables. This had not been in earlier studies. The two seasons are crop sowing and harvesting in Punjab and at the country level. Precipitation in Kharif season has significant positive $(\cap)$, mean minimum Kharif temperature has significant positive $(\cap)$ relationship with land prices. Mean maximum Kharif temperature is not significant with land prices. With respect to precipitation, it is found that an increase of one $\mathrm{mm}$ in precipitation, the land price on an average will increase by Pak Rs 166.577 per acre in Kharif season.

Precipitation in Rabi has significant negative (U) relationship, Mean minimum temperature has significant negative (U) and mean maximum Rabi temperature has significant positive ( $\cap$ shaped) relationship with land prices. Results have indicated that with decrease in Rabi precipitation coupled with an increase in maximum Rabi temperature will tend to increase the land price in the this season.

Population density and per capita income have positive relationship with land prices. Both these are very important control variables, and highly significant with price of land. The overall variables namely climate and non climate results explain in 93 percent variation in land prices as revealed by $R^{2}$ value.

The marginal climate impact is measured to capture the magnitude and also to check the joint significance of linear and squared coefficients of climate variables. Results have shown that in Rabi season, an increase in precipitation of one mm, agricultural land price, on an average, will decrease by Pak Rs 860 per acre. An increase in maximum temperature by $1^{\circ} \mathrm{C}$ will increase agricultural land price, on an average, by Pak Rs 25208.66 per acre.

\subsection{Policy Implications}

It has come out that all the climate variables, except maximum temperature, have highly significant relationship with land prices. Climate change is imposing cost, at the same brings-in benefits of increase in land prices in Rabi season due to increase in maximum temperature. Benefits show adaptation made by farmers in changing climate which leads to increase in long run net revenues.

The increase in precipitation in Kharif season tends to increase in land value. The increase in precipitation in Rabi season results in loss from decrease in production. The increase in mean minimum Rabi temperature being negatively significant imposes cost to agricultural sector with increase in temperature in this season. It is for the planners to evolve policies that benefits are maximised and costs are minimum as a result of climate change. To minimise cost, research and development pursuits of the concerned public and private institutions may be encouraged to develop heat and drought resistant varieties of currently cultivated crops. Incentive policies should be framed by policy makers for farmers to make switching from current varieties to the developed ones quickly happen. There should be flow of information at zero cost about changing climate for stakeholders. 


\subsection{Study Limitations}

In order to interpret the results correctly, the limitations need to be identified. The limitations arise primarily, due to non-availability of the requisite data. Data on irrigation was not taken in the model as these are not maintained by the irrigation authority on district level. The data are at the barrage or canal head level. The data on soil fertility and slope was also not used as GIS data is not tailored in according to requirements for time series.

Land price data obtained from Mutation register of Patwaris' at the district level which is very volatile. Research studies may be done by future researchers for other regions of the country also in the area of economic impact assessment. Cross sectional research studies may also be done as they use micro level household data for impact assessment.

\section{REFERENCES}

Amiraslany, A. (2010) The Impact of Cliamte Change On Candian Agriculture: A Ricardian Approach. Saskatoon, Saskatchewan: University of Saskatchewan. (Unpublished Thesis). Available at http://library2.usask.ca/theses/available/etd05252010-102012/.

Arrhenius, S. (1896) On the Influence of Carbonic Acid in the Air Upon the Temperature of the Ground. Philosophical Magazine and Journal of Science 41:5, 237-276.

Awan, K., J. O. S., and M. Whitehead (1982) Household Attributes and the Demand of Private Rental Housing. Economica 49, 183-200.

Bosello, F. and J. Zhang (2005) Assessing Cliamte Change Impacts:Agriculture. Social Science Research Network Electronic Paper Collection, 1-27.

Bureau of Statistics (Various Issues) Punjab Development Statistics. Lahore: Government of Punjab.

Colwell, P. and G. Dilmore (1999) Who Was Fit? An Examination of an Early Hedonic Study. Land Economics 74:4, 620-626.

Farooqi, A. and A. H. K. (2008) Climate Perspective in Pakistan. Workshop on Capacity Building on Global Climate Change. Islamabad.

Farooqi, A. and G. Rasul (1995) Water Requirement of Cotton Crop in Pakistan. Journal of Engineering and Applied Sciences 4:2, 154-165.

Freeman III, A. M. (2003) The Measure of Enviornmental and Resource Values: Theory and Methods. Washington, DC: Resource for the Future.

Goodman, A. C. (1978) Andrew Court and the Intervention of Hedonic Price Analysis. Journal of Urban Economy 44:2, 291-8.

Goulder, L. H. and W. A. Pizer (2006) The Economics of Climate Change. Resources for the Future. (Discussion Paper). Available at www.rff.org

Greene, W. H. (2003) Econometric Analysis. Singapore: Pearson Education.

Gunatillake, H. M. (2003) Enviornmental Valuation: Theory and Applications. Sri Lanka: Postgraduate Institute of Agriculture, University of Peradeniya.

Hass, G. (1922) Sale Prices as Basis for Farm Land Appraisal . The University of Minnesota Agricultural Experiment Station. (Technical Bulletin 9).

Heltberg, R., S. L. Jorgensen, and P. B. Siegel (2008) Climate Change, Human Vulnerability and Social Risk Management. Social Developmet Group, The World Bank Group. 
IAASTD (2008) Agriculture at Crossroads. Washington: Centre For Resouce for Economcis, Island Press.

IEA/OECD (2006) Key World Energy Statistics. Paris: International Energy Agency/ OECD.

IPCC (1996) Climate Change 1995: Impacts, Adaptations and Mitigation of Climate Change: Scientific-Technical Analyses. Cambridge: IPCC Second Assessment Report: Cliamte Change 1995. Cambridge: Cambridge University Press.

IPCC (2007) Climate Change 2007: The Physical Sciences Basis. Contribution of Working Group I to Fourth Assessment Report of the Intergovernmental Panel on Climate Change. Cambridge: Cambridge University Press, United Kingdom and New York, USA.

Iqbal, M. M., S. S. Hussain, M. A. Goheer, H. Sultana, K. M. Salik, M. Mudasser, and A. M. Khan (2009) Climate Change and Wheat Production in Pakistan: Calibration, Validation and Application of CERES-Wheat Model. Islamabad: Global Change Impact Studies Centre.

Iqbal, M. M., M. A. Goheer, S. A. Noor, K. M. Salik, H. Sultana, and A. M. Khan (2009) Climate Change and Rice Production in Pakistan: Calibration, Validation and Application of CERES-Rice Model. Islamabad: Global Change Impact Studies Centre.

Kaiser, H. M. and P. Crosson (1995) Implications of Climate Change for U.S. Agriculture. American Journal of Agricultural Economics 77:3, 734-740.

Kolstad, C. D. (2000) Enviornmental Economics. New York: Oxford University Press, Inc.

Kumar, K. (2009) Climate Sensitivity of Indian Agriculture Do Spatial Effects Matters? (SANDEE Working Papers, WP 45, 1-28).

Kumar, K. and J. Parikh (1998) Climate Change Impacts on Indian Agricultire: The Ricardian Approach, In A. Dinar, R. Mendelsohn, R. Evenson, J. Parikh, A. Sanghi, $\mathrm{K}$. Kumar, et al. (eds.) Measuring The Impact of Climate Change on Indian Agriculture. (World Bank Technical Paper No.42).

Kumar, K. and J. Parikh (2001) Socio-economic Impacts of Climate Cahnge on Indian Agriculture. International Review of Enviornmental Strategies 2:2, 277-293.

Ladd, G. and V. Suvannunt (n.d.) A Model for Consumer Demand for Good Characteristics. American Journal of Agricultural Economics 58, 504-510.

Lancaster, K. (1996) A New Approach to Consumer Theory. Journal of Political Eocnomy 74, 132-157.

Lippert, C., T. Kirmly, and J. Aurbacher (2008) A Ricardian Anlysis of the Impact of Cliamte Change on Agriculture in Germany. Institute of Farm Management 1.

Maclemman, D. (1977) Some Thoughts on the Nature and Purpose of Hedonic Price Functions. Urban Studies 14, 59-71.

Maddison, D. (2000) A Hedonic Analysis of Agricultural Land Prices in England and Wales. European Review of Agricultural Economics 27:4, 519-532.

Maddison, D. (2001) The Amenity Value of The Global Climate. London: Biddles Ltd.

Manne, A., R. Mendelsohn, et al. (1995) MERGE-A Model for Evaluating Regional and Global Effects of GHG Reduction Policies. 45:3, 17-34.

Mendelsohn, R., W. Nordhaus, and D. Shaw (1996) Cliamte Impacts on Aggregate Farm Value: Accounting for Adaptation. Journal of Agricultural and Forest Meteorology 80, 55-66. 
Pakistan, Government of (2009-10) Pakistan Economic Survey. Islamabad: Finance Division, Government of Pakistan.

Palmquist, R. (1991) Hedonic Methods. In J. B. Braden and C. D. Kolstad (eds.) Measuring the Demand for Enviornmental Quality. Amsterdam:Elsevier Science Publishing.

Polisky, C. (2004) Putting Space and Time in Ricardian Climate Change Impact Studies: Agriculture in the U. S. Great Plains, 1962-1992. Annals of the Association of American Geographers 94:3, 549-564.

Rasul, G., Q.-ul Zaman, A. Mahmood, and M. Afzal (2009) Climate Change Indicators of Paksitan. Islamabad: Pakistan Meteorological Department.

Reinsborough, M. J. (2003) A Ricardian Model of Cliamte Change in Canada. Canadian Journal of Economics 36:1, 27-31.

Roohi, R. (2004) Farm Mechanism Options under Climate Change Scenario in Pakistan. Islamabad: Natioanl Agricultural Research Centre.

Roohi, R., S. Ahmad, and A. Ashraf (2002) Characterisation and Classification of AgroClimate of Pakistan. Pakistan Journal of Agricultural Research 17:3.

Rosen, S. (1974) Hedonic Prices in Implicit Markets: Product Differentiation in Pure Competition. Journal of Political Economy 82:1, 34-55.

Rosenweigh, C. (1989) Global Climate Change Predictions and Observations. American Journal of Agricultural Economics 71:5, 1265-71.

Roson, R. and R. R. Palatnik (2009) Climate Change Assessment and Agriculture in General Equilibrium Model: Alternative Modeling Strategies. European Commission, 2-18.

Ryan, M. and H. J. (1997) Using Conjoint Analysis to Assess Women's Preferences for Miscarriage Management. Health Economics 6, 261-273.

Sadoulet, E. and D. A. (1995) Quantitative Developemnt Policy Analysis. London: Jhon Hopkins University Press.

Schelenker, W., W. Hanemann, and A. Fisher (n.d.) The Impact of Global Warming on U.S. Agriculture: An Econometric Analysis of Optimal Growing Conditions. Review of Economics and Statistics 88:1, 113-125.

Stock, J. H. and M. W. Watson (2003) Introduction to Econometrics. Singapore: Pearson Education.

Task Force on Climate Change (2010) Final Report. Islamabad: Planning Commision of Pakistan.

Wallace, H. (1926) Comaprative Farmland Values in IOWA. Jouranal of Land and Price Utility Economics 2, 385-92.

Wallace, N. E. (1996) Hedonic Price Indexes for Housing : Theory, Estimation and Index Construction. Federal Reserve Bank of San Fransisco Economic Revies 93-118.

Winter, P., R. Muragi, E. Sadoulet, and A. DeJavry (1996) Cliamte Change, Agriculture and Developing Economies. Department of Agriculture and Resource Economics, Division of Agriculture and Resource, University of California at Berkely. (Working Paper No. 785).

Witt, A. D. H. Sumka, and J. Erekson (1979) An Estimation of a Structural Hedonic Price Model of Housing Markets: An Application of Rosen's Theory of Implicit Markets. Econometrica 47, 1151-72. 
World Bank (2008) World Development Report: Agriculture for Development. Washington, DC: The World Bank.

World Bank (2010) World Development Report: Development and Climate Change. Washington, DC: The World Bank. 